\title{
The $X$ as Model for RNA's Niche in Epigenomic Regulation
}

\author{
Jeannie T. Lee \\ Howard Hughes Medical Institute, Department of Molecular Biology, Massachusetts General Hospital, \\ Department of Genetics, Harvard Medical School, Boston, Massachusetts 02115 \\ Correspondence: lee@molbio.mgh.harvard.edu
}

\section{SUMMARY}

The X-linked region now known as the "X-inactivation center" (Xic) was once dominated by protein-coding genes but, with the rise of Eutherian mammals some 150-200 million years ago, became infiltrated by genes that produce long noncoding RNA (ncRNA). Some of the noncoding genes have been shown to play crucial roles during X-chromosome inactivation $(\mathrm{XCl})$, including the targeting of chromatin modifiers to the $\mathrm{X}$. The rapid establishment of ncRNA hints at a possible preference for long transcripts in some aspects of epigenetic regulation. This article discusses the role of RNA in XCl and considers the advantages RNA offers in delivering allelic, cis-limited, and locus-specific control. Unlike proteins and small RNAs, long ncRNAs are tethered to the site of transcription and effectively tag the allele of origin. Furthermore, long ncRNAs are drawn from larger sequence space than proteins and can mark a unique region in a complex genome. Thus, like their small RNA cousins, long ncRNAs may emerge as versatile and powerful regulators of the epigenome.

\section{Outline}

\section{Introduction}

2 The unique challenges of $\mathrm{XCl}$

$3 \mathrm{XCI}$ 's repertoire of NCRNA regulators

4 RNA in pairing, counting, and choice
5 Symmetry break by Tsix RNA

6 Polycomb proteins targeted and regulated by RNA

References

Editors: John F. Atkins, Raymond F. Gesteland, and Thomas R. Cech

Additional Perspectives on RNA Worlds available at www.cshperspectives.org

Copyright (C 2010 Cold Spring Harbor Laboratory Press; all rights reserved; doi: 10.1101/cshperspect.a003749

Cite this article as Cold Spring Harb Perspect Biol 2010;2:a003749 


\section{INTRODUCTION}

It has become very fashionable to study long noncoding RNA (ncRNA). Given that only $1 \%-2 \%$ of the mammalian genome carries protein-coding information, genomicists have oft pondered the relevance of the remaining $98 \%$ which, as a whole, bear little phylogenetic conservation among any except for the most closely related species. It is by now clear, however, that the vast intergenic space is anything but quiescent. An astounding 70\%-90\% of our nucleotides are apparently transcribed (Kapranov et al. 2007b; Mercer et al. 2009). The mouse and human transcriptomes contain 80,000-180,000 RNAs (Carninci et al. 2005; Wheeler et al. 2008), the majority of which lack conserved open reading frames and belong to a rising class of transcripts formerly thought to be "junk," ranging in size from $50 \mathrm{nt}$ to $>100 \mathrm{~kb}$. Affectionately dubbed "macroRNA," they are distinct from catalytic and structural RNAs, as well as the well-known small RNAs of the RNA-interference pathway (Cam et al. 2009; Cech 2009; Ghildiyal and Zamore 2009; Moazed 2009; Sharp 2009), and can be antisense, promoter-associated, or intergenic (Claverie 2005; Katayama et al. 2005; Kapranov et al. 2007a; Kapranov et al. 2007b; He et al. 2008; Guttman et al. 2009; Khalil et al. 2009; Mercer et al. 2009). Whether they possess function or are merely incidental biproducts of genome activity remains unknown, but many are clearly developmentally regulated and linked to genes with undisputed function.

Although the occurrence of genome-wide transcription has sparked widespread interest in long ncRNA only recently, such RNAs have captivated investigators in some fields for some time. Epigeneticists have long been drawn to the mystique surrounding RNA behemoths, beginning with the discovery of the 2.6-kb H19 RNA in the field of genomic imprinting (Brannan et al. 1990; Bartolomei et al. 1991) and the 17-kb XIST RNA for X-chromosome inactivation (XCI) (Borsani et al. 1991; Brown et al. 1991a; Brockdorff et al. 1992; Brown et al. 1992). Genes subject to imprinting are expressed from only one of two alleles in a manner dependent on parent of origin, and such genes are almost always clustered within domains and coordinately regulated in cis by a single (sometimes two) "imprinting centers" (Edwards and Ferguson-Smith 2007; Wan and Bartolomei 2008). Likewise, XCI-the mechanism of dosage compensation in mammals-is a domain phenomenon that extends to include the entire X-chromosome (Lyon 1961; Wutz 2003; Lucchesi et al. 2005; Masui and Heard 2006; Wutz and Gribnau 2007; Payer and Lee 2008). During $\mathrm{XCI}$, almost all of the $\sim 1000$ protein-coding genes on one of two X-chromosomes become transcriptionally inactivated in cis by a single control region known as the
"X-inactivation center" (Cattanach and Isaacson 1967; Rastan and Robertson 1985). Because the nature of XCI is also allelic, silencing must be coordinately controlled to take place only on genes of one chromosome. Thus, imprinting and XCI are unified by the fact that a small control region exerts long-range effects on chromatin and by the allelic nature of the regulatory process.

The existence of two macroRNAs for two quintessentially "epigenetic" phenomena brought early suspicion that RNA may be central to the control of epigenetic inheritance. The subsequent discoveries of the regulatory antisense RNAs, Airn for the imprinted Igf2r locus (Wutz et al. 1997) and Tsix for XCI (Lee et al. 1999a; Lee and Lu 1999)—-themselves even longer ncRNAs—raised that level of suspicion. The emerging understanding that Tsix RNA may help target DNA methylation by Dnmt3a and other chromatin modifiers, either directly or indirectly, to the Xist promoter suggested that RNA may be a recruiting tool for chromatin modifiers on the X (Navarro et al. 2005; Sado et al. 2005; Sun et al. 2006). That RepA RNA directly binds and targets Polycomb proteins to the $\mathrm{X}$ then argued that RNA may be a direct mechanism for recruiting specific enzymatic activities in cis (Zhao et al. 2008). The antisense Airn and Kcnq1ot1 RNAs have also been hinted to play similar roles at imprinted loci, by direct or indirect means (Nagano et al. 2008; Pandey et al. 2008). Such findings have brought recognition of RNA's potential in regulating our epigenomic landscape in cis and led to further ruminations about the possible roles of pervasive noncoding transcription in our genomes.

This article will develop the concept of RNAs as effectors of choice by drawing examples from the XCI paradigm. To date, at least seven distinct noncoding genes have been found within the $\mathrm{X}$-linked region loosely defined as the "X-inactivation center" (Xic), a 100-500-kb domain with few, if any, protein-coding genes (Brown et al. 1991b; Lee et al. 1996; Simmler et al. 1996; Willard 1996; Lee et al. 1999b; Chureau et al. 2002). Why have long ncRNAs come to dominate the Xic landscape? RNA's supremacy seems to imply that this nucleic acid polymer offers something that proteins do not (Lee 2009). Herein, I will argue that RNA is ideally suited to epigenetic inheritance, particularly in cases that demand allelic regulation (cis effects) and action at a single locus (singularity).

\section{THE UNIQUE CHALLENGES OF XCI}

XCI presents a number of interesting challenges. Two $\mathrm{X}$-chromosomes sharing the same nucleus must be treated in diametrically opposite ways during early development. There is first the problem of chromosome counting - the determination of whether it possesses one (XY) or two 
$\mathrm{Xs}(\mathrm{XX})$ and whether it should therefore initiate XCI. Genetic analyses have shown that an X:autosome ratio of 1 or greater triggers the XCI cascade (Kay et al. 1994; Lyon 1999; Avner and Heard 2001; Boumil and Lee 2001) and that noncoding elements of the Xic influence the X:A ratio (Clerc and Avner 1998; Morey et al. 2004; Lee 2005; Donohoe et al. 2009; Monkhorst et al. 2009).

There is second the problem of X-chromosome choice, which implies the existence of a random selection mechanism that chooses the active $\mathrm{X}(\mathrm{Xa})$ and the inactive $\mathrm{X}$ (Xi) in a mutually exclusive manner (Lee 2002). The mutually exclusive nature of choice necessitates communication between the Xs in trans to ensure that a cell does not adopt the lethal XaXa or XiXi fate. This second step of XCI requires the action of noncoding genes as well.

Finally, silencing factors must be recruited to the future $\mathrm{Xi}$ in a colinear fashion, spreading along the chromosome in a strictly cis-limited manner and without trans effects on homologous loci of the future Xa. It is widely believed that inactivation begins at the Xic before spreading outwardly to encompass the rest of the X-chromosome. During XCI, the $\mathrm{Xi}$ becomes distinguished from Xa by its enrichment for Polycomb proteins, the SET domain protein HP1, variant histones such as macroH2A, and a number of distinct chromatin modifications (Plath et al. 2002; Wutz 2003; Lucchesi et al. 2005; Payer and Lee 2008). How heterochromatinization and gene silencing are coordinated along 1000 genes of the $\mathrm{X}$ remains a largely unsolved problem, but there is widespread belief that Xist RNA is the messenger of the $X i c$, that it spreads along the $\mathrm{X}$, and that this action is directly responsible for reprogramming the chromosome's gene expression state.

\section{$3 X$ XCI'S REPERTOIRE OF NCRNA REGULATORS}

At least seven noncoding loci have been identified within the $100-$ to $500-\mathrm{kb}$ region in or around the Xic (Brown et al. 1991b; Lee et al. 1996; Simmler et al. 1996; Willard 1996; Lee et al. 1999b; Chureau et al. 2002) (Fig. 1A). Several have been shown to play vital roles during XCI (Fig. 1B). The 17-kb Xist RNA is transcribed only from the $\mathrm{Xi}$ and its accumulation on the $\mathrm{X}$ is thought to induce chromosome-wide silencing by binding and spreading silencing complexes throughout the $\mathrm{X}$ in cis (Brockdorff et al. 1992; Brown et al. 1992; Clemson et al. 1996; Penny et al. 1996; Marahrens et al. 1997). Embedded within the $5^{\prime}$ end of the Xist locus is a repeated motif known as "Repeat A" (Brown et al. 1992), previously shown to be essential for Xist RNA's silencing function (Wutz et al. 2002). It is now known to encode a separate transcription unit, named "RepA." RepA RNA directly binds Polycomb proteins and recruits them to the Xic in an action that paradoxically activates Xist expression and the initiation of XCI (Zhao et al. 2008).

The actions of RepA and Xist RNAs are controlled by Tsix, a 40-kb ncRNA that is antisense to both RNAs (Lee et al. 1999a; Lee and Lu 1999; Lee 2000; Luikenhuis et al.

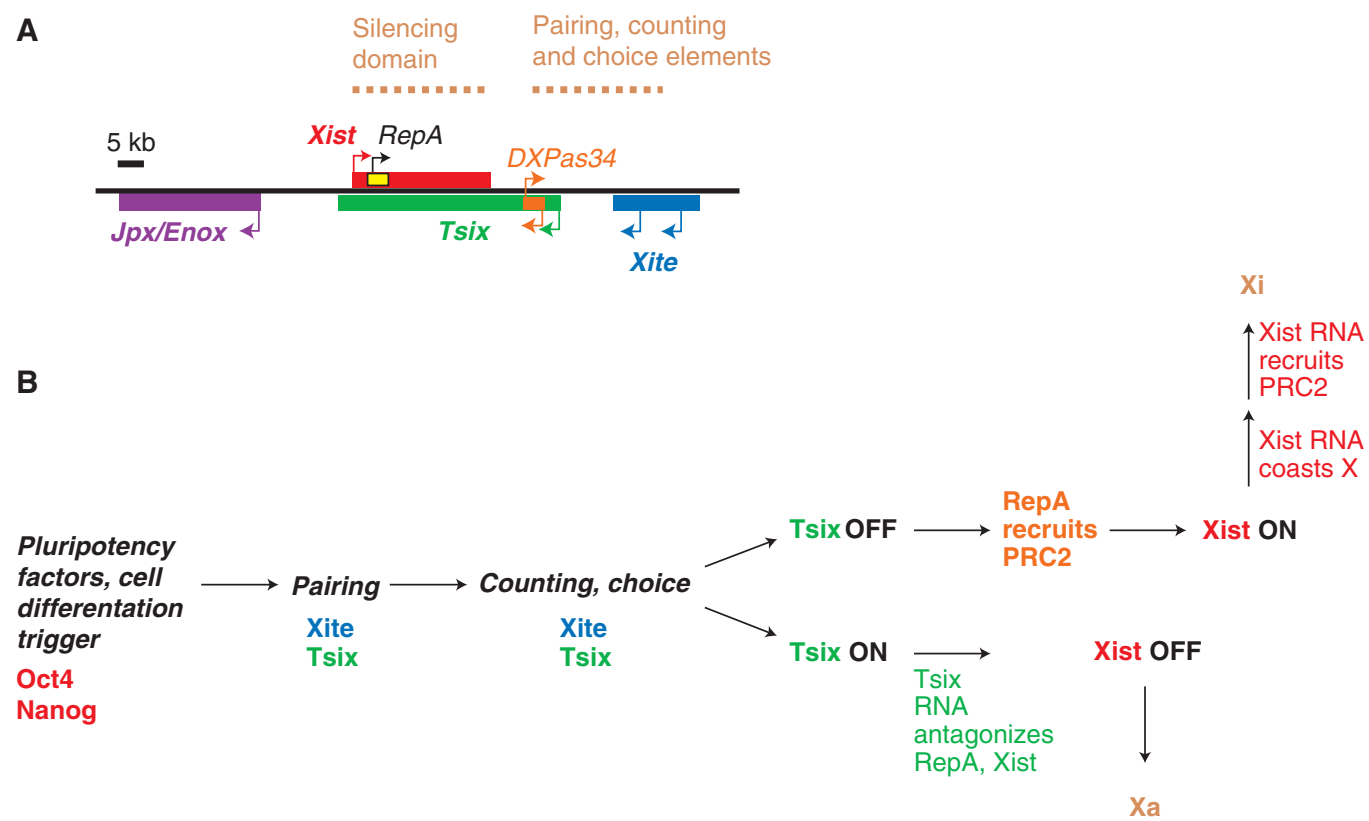

Figure 1. The X-inactivation center, its noncoding genes, and their functions during the XCI cascade. $(A)$ More than seven noncoding genes have been found within or around the Xic. Xist, RepA, Tsix, and Xite have ascribed function. The regions responsible for X-chromosome pairing, counting/choice, and spreading/silencing are indicated. (B) Steps of XCI and the factors known to regulate them. 
2001; Sado et al. 2001). Tsix bears a crucial relationship to Xist (Fig. 2). In undifferentiated cells (pre-XCI), Tsix is expressed on both Xs. During this stage, Xist RNA is expressed at extremely low "basal" levels. At the onset of cell differentiation, Tsix persists only on the chromosome selected to become Xa. It is the persistence of Tsix RNA that prevents the up-regulation of Xist on Xa. Conversely, the down-regulation of Tsix on $\mathrm{Xi}$ creates a permissive state for Xist transactivation. Whether Tsix RNA will persist during cell differentiation is controlled by the upstream locus, Xite. Xite harbors a developmentally regulated enhancer that maintains expression of Tsix on $\mathrm{Xa}$ and prevents inactivation of Xa (Ogawa and Lee 2003; Stavropoulos et al. 2005). Thus, the ncRNAs have a Yin-yang relationship to each other, with RepA and Xist RNAs promoting the initiation of XCI, and Xite and Tsix RNAs blocking that action.

Several other ncRNAs have been identified, including Jpx/Enox (Chureau et al. 2002; Johnston et al. 2002), Ftx (Chureau et al. 2002), and the bidirectional transcripts (Cohen et al. 2007) associated with a repeat element called “DXPas34," located at Tsix's 5' end (Courtier et al. 1995; Debrand et al. 1999). Small RNAs of 21-42 nucleotides are also observed in this region, presumably cleaved from long Xist/Tsix RNA duplexes (Ogawa et al. 2008). Although some ncRNAs remain uncharacterized, several have well-defined roles and their mechanisms of action have come into sharper focus during the past years. The discrete roles of four noncoding genes-Xite, Tsix, RepA, and Xist-will be discussed in the next sections.

\section{RNA IN PAIRING, COUNTING, AND CHOICE}

In the widely used embryonic stem (ES) cell model, XCI is triggered directly by decreasing Oct4 levels and the onset of cell differentiation (Monk and Harper 1979; Navarro et al. 2008; Donohoe et al. 2009). Evidence suggests that "counting" involves interaction between Oct4 and a $15-\mathrm{kb}$ region encompassing Xite and the $5^{\prime}$ end of Tsix (Fig. 1A)(Clerc and Avner 1998; Morey et al. 2004; Lee 2005; Donohoe et al. 2009). This same region has also been shown to function during "choice," Its mutually exclusive nature implies interchromosomal communication to ensure that each cell acquires exactly one Xa and one Xi (Marahrens 1999; Lee 2005). Recent studies have proposed that homologous $\mathrm{X}$-chromosome "pairing" may mediate communication in trans and, in doing so, help achieve correct counting and choice of Xa and Xi (Bacher et al. 2006; Xu et al. 2006; Xu et al. 2007; Donohoe et al. 2009). Time course analyses have indicated that the Xs make very brief contact $\left(t_{1 / 2}<30-60 \mathrm{~min}\right)$ shortly after the onset of cell differentiation and just before the up-regulation of Xist RNA (Xu et al. 2007). When pairing is disrupted genetically or pharmacologically, cells adopt either the XaXa or XiXi phenotype and they die or arrest in culture. Thus, pairing achieves counting and the mutually exclusive choice of $\mathrm{Xa}$ and $\mathrm{Xi}$ by providing a platform for inter-chromosomal communication and by breaking symmetry between two X-chromosomes (Bacher et al. 2006; Xu et al. 2006; Nicodemi and Prisco 2007b).

Unlike homologous pairing during meiosis and in somatic cells of fruitflies, X-X pairing does not involve whole chromosomes-it occurs only at the Xic. Not surprisingly, pairing elements coincide with those responsible for counting and choice in the $15-\mathrm{kb}$ region including Xite and Tsix (Xu et al. 2006)(Fig. 1A). Deleting $3.7 \mathrm{~kb}$ of sequence at the $5^{\prime}$ end of Tsix on both X-chromosomes abrogates pairing. For Xite, deleting even just one allele severely compromises pairing potential in female cells. Tsix and Xite are not only required but are also sufficient to induce pairing. When

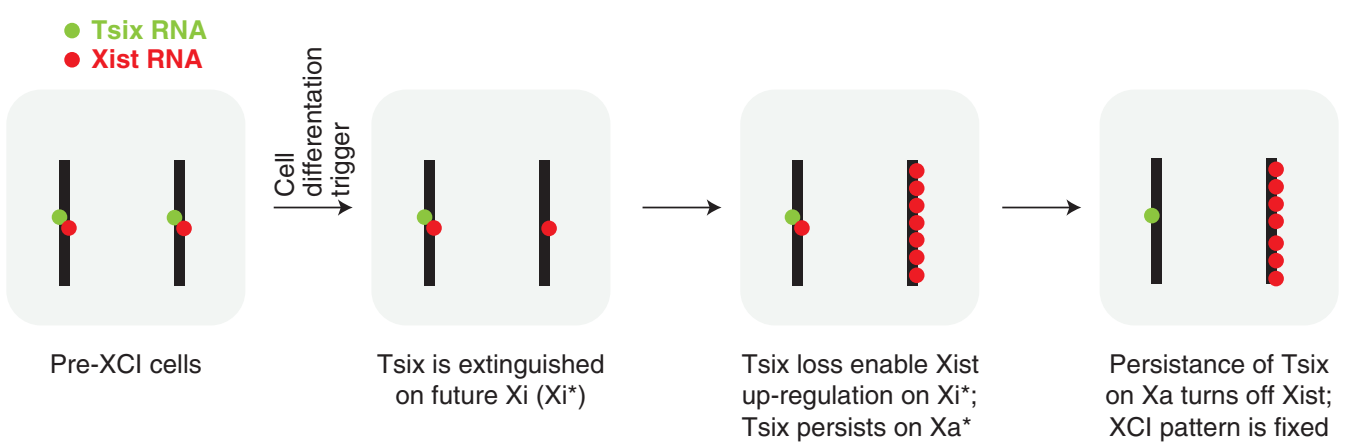

Figure 2. Yin-Yang relationship between Tsix and Xist RNAs. Tsix bears a critical relationship to Xist expression. In undifferentiated cells ( pre-XCI), Tsix is expressed from both Xs at high levels and Xist RNA is expressed at low basal levels ( $\sim 5$ copies). At the onset of cell differentiation, Tsix persists only on the chromosome selected to become Xa. It is the persistence of Tsix RNA that prevents the up-regulation of Xist on Xa. Conversely, the down-regulation of Tsix on Xi creates a permissive state for Xist transactivation and spread of the RNA along the X to initiate chromosomewide silencing. Tsix is eventually turned off on Xa once the pattern of XCI is fixed. 
inserted at ectopic locations in the genome, Tsix and Xite direct pairing of the $\mathrm{X}$ with the chromosome into which they are inserted (Bacher et al. 2006; Xu et al. 2006). Unexpectedly, pairing can be induced by $1-3-\mathrm{kb}$ fragments that carry very diverse sequences, and even sequences of very low complexity recapitulate pairing. For example, a 1.6-kb element (DXPas34) carrying a 34-nucleotide motif repeated 29 times induces $\mathrm{X}$-autosome interactions when multimerized on autosomes (Xu et al. 2007).

How do elements of such diverse nature and low complexity drive two chromosomes together? Two interesting features are shared by most if not all pairing-competent sequences (Xu et al. 2007). First, they bind Ctcf protein, an 11-Zn finger protein involved in many aspects of epigenetic regulation (Lobanenkov et al. 1990; Bell et al. 1999; Ohlsson et al. 2001; Kim et al. 2007). Ctcf has a large number of binding sites within Tsix and Xite loci and is thought to function as a transcriptional activator of both genes (Chao et al. 2002; Xu et al. 2007). Ctcf interacts with Oct4, a pluripotency factor thought to trigger counting as Oct4 levels fall during cell differentiation, and knocking down either Ctcf or Oct4 leads to an abrogation of pairing in ES cells (Donohoe et al. 2009; Xu et al. 2007).

Sequences sufficient for pairing also share transcriptional competence, a fact that raises the intriguing possibility of an RNA requirement. Despite their diversity of sequence and low sequence complexity, nearly all pairingcompetent fragments show Pol-II promoter activity (Sado et al. 2001; Ogawa and Lee 2003; Stavropoulos et al. 2005; Cohen et al. 2007; Xu et al. 2007). Inhibiting Pol-II transcription by a $2.0-4.0 \mathrm{~h}$ actinomycin $\mathrm{D}$ treatment completely inhibits $\mathrm{X}-\mathrm{X}$ pairing, indicating that new transcription is necessary for $\mathrm{X}$-chromosome coupling (Xu et al. 2007). In contrast, inhibiting Pol-II for as little as $0.5 \mathrm{~h}$ disrupted new pair formation but did not affect cohesion of previously formed pairs. Time course analysis shows that cohesion of the previously formed pairs decayed with a half-life of $\sim 0.5-1.0 \mathrm{~h}$. Combined, these data show that pairing is very transient and that an RNA, or the act of transcribing it, is crucial for formation of new $\mathrm{X}$-chromosome pairs.

It is therefore proposed that a complex of RNA and protein mediates X-X pairing (Fig. 3). In undifferentiated pre-XCI cells, Oct4 and Ctcf proteins would dimerize and bind Tsix and Xite to activate expression of the ncRNAs. Falling Oct4 levels during differentiation would then trigger trans-association of the Xic's in an RNA-dependent manner. The trans-interactions would then lead to physical differences between two Xs and signal one to become Xa and the other Xi. For example, proximity of Xic's might result in the irreversible shift of protein factors such as Oct4 and Ctcf — which are initially bound to both $X i c$ 's - from one Xic (future Xi) to the other (future Xa) (Xu et al. 2006; Xu et al. 2007; Donohoe et al. 2009). Although this idea has yet to be tested, computational modeling suggests that, under certain conditions, the shift of factors to one chromosome could create greater thermodynamic stability (Nicodemi and Prisco 2007a; Nicodemi

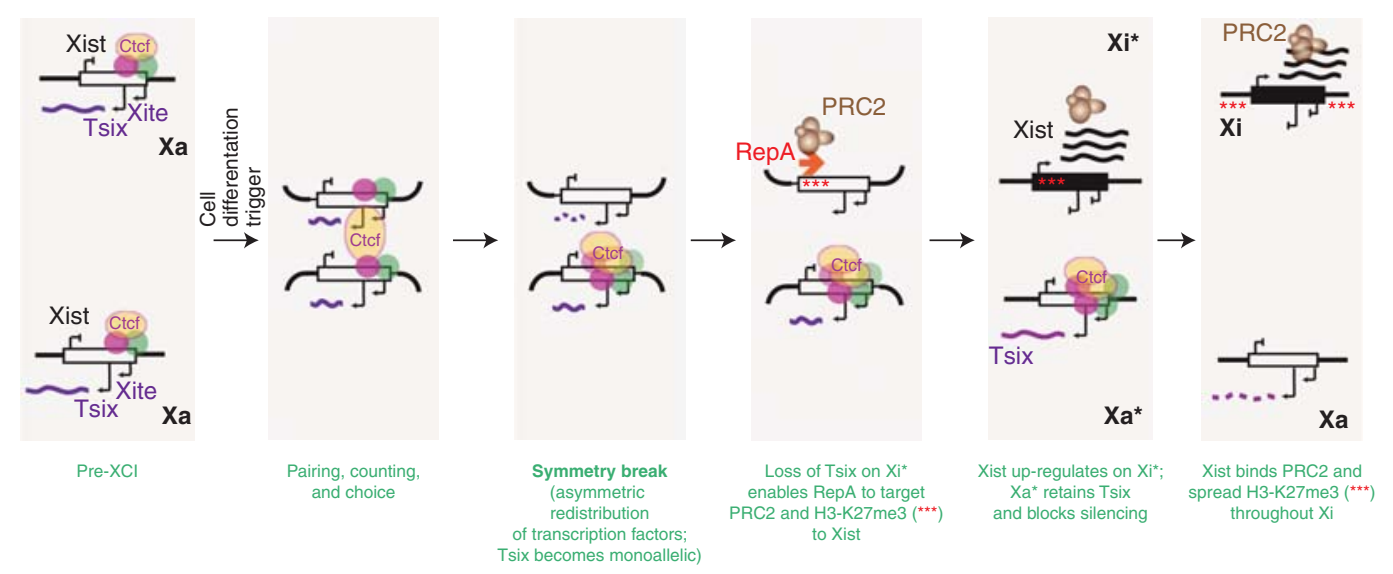

Figure 3. Symmetry break mediated by pairing and Tsix. Adapted from (Anguera et al. 2006) and (Lee 2009): In the pre-XCI state, the Xs are epigenetically equivalent, both expressing Tsix at high levels and Xist at low basal levels. Falling levels of Oct4 during cell differentiation triggers X-X pairing. Pairing is mediated by Ctcf, Tsix, and Xite and enables cross-talk to achieve correct counting and mutually exclusive $\mathrm{Xa}$ and $\mathrm{Xi}$ fates. Transcription factors such as Ctcf, Oct4, and others (red, green circles), which were previously randomly distributed between the two $\mathrm{Xs}$, shift to bind one $\mathrm{X}$, a state that is thermodynamically favored. The chromosome that retains the transcription factors maintains Tsix expression and becomes Xa. Loss of factor binding on the future Xi enables RepA to target PRC2 and H3-K27me3 to the $5^{\prime}$ end of Xist, an event that leads to Xist's transcriptional activation. Xist RNA spreads along the future Xi and recruits PRC2 to it to initiate chromosome-wide silencing. 
and Prisco 2007b; Nicodemi et al. 2008). This shift of activators would then result in allele-specific persistence of Tsix on the future Xa, which in turn would establish the necessary $\mathrm{X}$-chromosome asymmetry. In this way, the pairing of X's makes possible both the counting of X's and the mutually exclusive choice of $\mathrm{Xa}$ and $\mathrm{Xi}$ at the onset of cell differentiation.

\section{SYMMETRY BREAK BY TSIX RNA}

Such a model suggests that pairing generates asymmetric Tsix expression and that Tsix must therefore function as a molecular switch for XCI. Accordingly, Tsix is one of the most heavily mutagenized genes in the history of mouse genetics. Toward understanding its mechanism of action, multiple knockouts, knock-ins, and transgene manipulations have been created to delete, truncate, overexpress, and transplant parts or all of the antisense RNA (Lee et al. 1999a; Lee and Lu 1999; Lee 2000; Luikenhuis et al. 2001; Sado et al. 2001; Stavropoulos et al. 2001; Sado et al. 2002; Morey et al. 2004; Shibata and Lee 2004; Lee 2005; Ohhata et al. 2006; Sado et al. 2006; Xu et al. 2007; Ohhata et al. 2008; Shibata et al. 2008). Abrogating Tsix expression results in constitutively elevated Xist expression, whereas its forced expression prevents Xist up-regulation. Such analyses have shown that not only does Tsix participate in the most upstream steps of XCI (counting, choice, pairing), but it also plays an active role during cell differentiation. Indeed, it is Tsix's binary state during cell differentiation that breaks X-chromosome symmetry (Fig. 3).

In the pre-XCI cells, both alleles of Tsix are expressed, with the consequence that both Xist alleles are uninduced (very low level, basal expression state). Time course analyses of chromatin structure using chromatin immunoprecipitations (ChIP) have revealed dynamic changes during cell differentiation. Several of the analyses show that Tsix regulates Xist by modulating the chromatin state of the Xist promoter (Navarro et al. 2005; Sado et al. 2005; Navarro et al. 2006; Sun et al. 2006). One study followed allelic differences in female ES cells during XCI and found that Xist promoter's configuration mirrored that of Tsix's transcriptional state (Sun et al. 2006). When Tsix is expressed in pre-XCI cells, both Xist alleles are maintained in an open chromatin state. During cell differentiation, loss of Tsix on the future $\mathrm{Xi}$ results in a closed chromatin conformation along the 40-kb Tsix/Xist locus. The repressive chromatin strangely correlates with Xist transactivation, as the $5^{\prime}$ end of Xist becomes H3-K27 trimethylated (H3-K27me3) just prior to the 100-fold induction of Xist transcription (see next section for further discussion). These unexpected results suggested that Xist expression may, paradoxically, be enhanced by repressive chromatin.
On the future Xa, cell differentiation leads to continued expression of Tsix, which in turn maintains the domain in an open state that is enriched for H3-K4 methylation and $\mathrm{H} 4$ acetylation and depleted of H3-K27 trimethylation. This "open" chromatin configuration occurs on the repressed Xist allele. RNA ChIP in ES cells suggests that Tsix RNA complexes with the de novo methyltransferase, Dnmt3a, and facilitates CpG methylation and silencing of the Xist promoter (Sun et al. 2006), consistent with in vivo analysis in Tsix-deficient and Dnmt3a-deficient mice (Sado et al. 2004; Sado et al. 2005). Interestingly, small RNAs can be generated from longer Tsix:Xist RNA duplexes in vivo, a finding that raises the possibility of RNA-directed DNA methylation and transcriptional gene silencing (Ogawa et al. 2008). Consistent with this idea, Dicer-deficient ES cells, which have markedly reduced small RNA production, have reduced Xist DNA methylation and significantly increased Xist RNA levels (Nesterova et al. 2008; Ogawa et al. 2008; Kanellopoulou et al. 2009). These results lead to a working hypothesis in which Tsix RNA maintains the activity of the $\mathrm{X}$ in two ways-first by directing euchromatic modifications to the Xist locus and paradoxically blocking Xist activation, and second by recruiting Dnmt3a activity to $\mathrm{CpG}$-methylate and stably silencing the Xist promoter (Fig. 4).

Therefore, Tsix's binary state- "off" on Xi and "on" on $\mathrm{Xa}$ - underlies the asymmetry of XCI. A crucial aspect of the mechanism may be that the chromatin states of Tsix and Xist are intimately locked together, such that when Tsix is euchromatic, Xist is also; when Tsix is heterochromatic, Xist is likewise. This lock-step relationship elicits the obvious question of why their expression patterns do not also mirror each other-and in fact are even diametrically opposed. It is in this paradox, we believe, that one of the challenges of XCI is met. We suppose that Tsix and Xist thrive in opposite chromatin environments, with Tsix being activated by open chromatin, and Xist being repressed by it. This unusual structure-function relationship serves XCI exceptionally well, when considered from the standpoint that Xist must escape inactivation on the $\mathrm{X}$ that it ultimately silences. A gene that is activated by heterochromatin and remains robust in it would be singularly suited to both initiate and maintain the $\mathrm{Xi}$ state.

\section{POLYCOMB PROTEINS TARGETED AND REGULATED BY RNA}

Here we consider how Xist is induced and initiates chromosome-wide silencing. One of the first changes to occur during the silencing step is the recruitment of Polycomb repressive complex 2 (PRC2). PRC2 contains four 


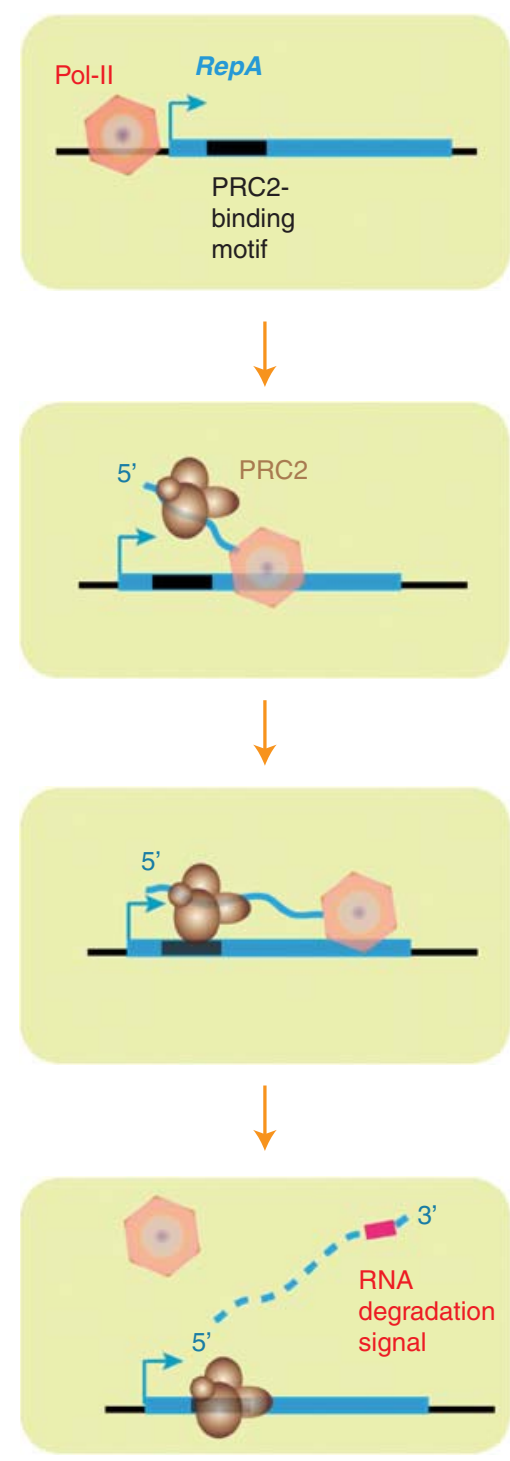

Pol-II initiates RepA transcription.

The PRC2-binding domain at the 5' end of RepA RNA is revealed; the RNA remains tethered to the allele via the 3 ' end.

PRC2 is targeted to the $X$ in cis by tethered RNA.

Figure 4. Long ncRNAs recruit chromatin modifiers in a cis-limited and locus-specific manner. The example of PRC2 recruitment by RepA RNA is shown.

subunits (Eed, Ezh2, Suz12, and RbAp46/48) and belongs to the Polycomb group (PcG) family of proteins that have genome-wide roles in the maintenance of stem-cell identity, proper developmental progression, and etiology of diseases such as cancer (Ringrose and Paro 2004; Schwartz and Pirrotta 2008). How Polycomb complexes are recruited to specific genomic locations remains unclear. Drosophila PcG complexes are known to contain sequence-specific DNA binding proteins such as Zeste, Pipsqueak (PSQ), and Pho, but whether mammalian complexes also contain such DNA-binding proteins remains somewhat controversial (Ringrose and Paro 2004; Schwartz and Pirrotta 2008). The possibility of an RNA cofactor was initially raised by the curious observation that PcG complexes become unstable when treated with RNAse (R. Paro, personal communication). Experimental evidence first came to light with the discovery of HOTAIR for human HOX gene regulation (Rinn et al. 2007) and RepA for XCI (Zhao et al. 2008).

XCI has provided a convenient model to study Polycomb regulation, as PRC2 is localized en masse to the $\mathrm{X}$ almost immediately following Xist RNA accumulation (Plath et al. 2003; Silva et al. 2003; Kohlmaier et al. 2004). As discussed in the previous section, one of the first changes to follow Tsix down-regulation is appearance of a PRC2 and H3-K27me3 domain at the $5^{\prime}$ end of Xist (Sun et al. 2006; Zhao et al. 2008). PRC2 is brought there in cis by RepA RNA, a $1.6 \mathrm{~kb}$ ncRNA originating from the $5^{\prime}$ end 
of Xist, precisely in the region showing $\mathrm{H} 3-\mathrm{K} 27 \mathrm{me} 3$ activity. RepA consists of 7.5 tandem repeats of two stemloop structures (Wutz et al. 2002), and is transcribed in the same orientation as Xist. RNA gel shift analysis shows that RepA RNA directly interacts with PRC2 through its 28-nt stem loop structures and binds the catalytic subunit, Ezh2 (Zhao et al. 2008). RepA is apparently sufficient to recruit PRC2, as when an inducible RepA transgene is placed at an ectopic location, increased recruitment of PRC2 can be observed. Importantly, this recruitment is observed only when RepA is transcribed (transgene expression induced by doxycycline treatment). When a transcribed RepA RNA is knocked down by shRNA, PRC2 recruitment in cis is significantly disrupted. Taken together, these experiments show that RepA functions as a ncRNA and directly targets PRC2 to the Xic.

RepA-mediated PRC2 recruitment and H3-K27 trimethylation of the Xist promoter are believed to create the "heterochromatic state" (Sun et al. 2006)(discussed in the previous section) that is required for transcriptional induction of Xist. Indeed, knocking down RepA RNA and PRC2 components (Zhao et al. 2008) or knocking out the Repeat A motif in mice (Hoki et al. 2009) results in the inability to activate Xist expression. In undifferentiated ES cells, RepA RNA is biallelically expressed and binds PRC2 without catalyzing H3-K27 trimethylation. During cell differentiation, the down-regulation of Tsix RNA on the future $\mathrm{Xi}$ allows the RepA-PRC2 complex to load onto the Xist chromatin and induce H3-K27me3, an event that would then lead to activation of the Xist promoter, accumulation of Xist RNA, and its spread along the X. RNA immunoprecipitations (RIP) show that Xist RNA can also bind PRC2, presumably via the Repeat A motif, which it shares with RepA. Because Xist RNA greatly exceeds the length of RepA and contains a number of putative chromosome-binding domains (Wutz et al. 2002), Xist RNA can perform what RepA RNA cannot-the spreading of PRC2 along the rest of the X-chromosome.

In the course of characterizing the RepA-PRC2 interaction by RNA EMSA, it was discovered that the antisense strand of RepA-i.e., Tsix-could bind PRC2 (Zhao et al. 2008). Similarly, RIP analysis in ES cells indicated that Tsix RNA occurred in a complex with PRC2. These unexpected findings led to the idea that Tsix RNA might act as a competitive inhibitor for PRC2. Several mechanisms could be envisioned. First, if Tsix and RepA bound PRC2 in a mutually exclusive manner, Tsix RNA could directly compete with RepA RNA for PRC2. Because Tsix is present in vast molar excess over RepA RNA $(\sim 100: 1)$ in undifferentiated ES cells (Shibata and Lee 2003), formation of a Tsix-PRC2 complex would be stoichiometrically favored over a RepA-PRC2 complex. Alternatively, Tsix RNA could block loading of the RepA-PRC2 complex to chromatin, or interfere with PRC2's catalytic activity-both of which would be consistent with the fact that H3-K27me3 on Xist is not observed until Tsix RNA is down-regulated (Zhao et al. 2008). Whether PRC2 binds both sense and antisense strands at the same time or mutually exclusively is not known. Pretreating RIP samples with ribonucleases showed that the RNAs were destroyed in the presence of RNAse I and RNAse V1, which digest ssRNA and dsRNA respectively, but digesting with RNAse $\mathrm{H}$ and DNAse I did not affect RIP pulldowns. Therefore, RNA bound by PRC2 possess both single-stranded (ss) and doublestranded (ds) character and is not annealed to DNA. The bound transcript(s) may be a single strand of RNA with intramolecular basepairing (secondary structure) or an RNA duplex formed by RepA and Tsix RNAs. The existence of such duplex RNA is supported by in vivo RNAse protection assays in ES cells (Ogawa et al. 2008).

Taken together, these results suggest that ncRNAs play three roles during the initiation of the silencing step (Fig. 3): (1) In undifferentiated ES cells and on the future $\mathrm{Xa}$ of differentiating cells, high levels of Tsix RNA prevent the initiation of XCI by interfering with the RepA-PRC2 complex. (2) When Tsix is down-regulated on the future $\mathrm{Xi}$, RepA RNA productively engages PRC2, targets the Polycomb activity to the Xist promoter, and triggers the 100-fold up-regulation of Xist RNA by trimethylating $\mathrm{H} 3-\mathrm{K} 27$ to create a patch of heterochromatin at the $5^{\prime}$ end of Xist. (3) Xist then binds PRC2 and spreads PRC2 and its $\mathrm{H} 3-\mathrm{K} 27$ trimethylase activity along the $\mathrm{X}$ to initiate chromosome-wide silencing.

\subsection{The Advantages of Long ncRNA}

The X-linked region that is now the $\mathrm{X}$-inactivation center was once dominated by protein-coding genes (Duret et al. 2006). Comparative genomic analysis suggests that ncRNAs infiltrated the region (and transformed the original coding residents) only within the last 120-150 million years with the rise of eutherian mammals and the evolution of random XCI. The marsupial mammal, which uses an imprinted form of XCI (Sharman 1971), completely lacks an Xic and its noncoding genes (Duret et al. 2006; Davidow et al. 2007; Hore et al. 2007; Shevchenko et al. 2007). Clearly, ncRNAs of the Xic established themselves very quickly and effectively within a short space of time. Does RNA's preeminence here hint at similar strategies elsewhere in the genome, especially considering the degree of noncoding transcription that is now known to occur generally? For epigenetic regulation, there may be two simple reasons to favor RNA over protein (and small molecules). I contend that RNAs deliver superior cis-control of allelism 
and make possible the targeting of a unique genomic location (Lee 2009).

Unlike proteins and small RNAs, large ncRNAs are stably tethered to the site of transcription and therefore tag the allele of origin. Because a long ncRNA remains bound via RNA polymerase to its parent locus during the act of transcription, the large RNA presents itself as a sequence-specific tag for the locus. The proteome cannot serve this function, as memory of allelic origin is always lost once mRNA detaches from the locus and exits the nucleus to be translated to protein. The ncRNA tags must be lengthy, with a $5^{\prime}$ "business end" that binds its target protein(s) once the RNA is synthesized and exposed, and a transcriptionally lagging $3^{\prime}$ "tethering end" that remains associated with the transcription machinery and chromatin (Fig. 4). With the potential to be locus-specific "beacons," long ncRNA may be the missing link between chromatin modifier and genomic target. It is probably no coincidence that the Repeat A motif is at the proximal terminus of both RepA and Xist RNAs. This strategic position enables the RNAs to bind PRC2 co-transcriptionally and tether the proteins to the $\mathrm{X}$ in cis. If the RNA is then destabilized by degradation signals at the $3^{\prime}$ end that would be revealed by Pol-II as transcription is completed, the RNA could be prevented from diffusing away from the site of synthesis. In this manner, long ncRNAs such as RepA and Xist RNA could function monoallelically and act strictly in cis.

Large ncRNAs are drawn from larger sequence space than proteins and can therefore achieve greater sequence specificity. The diversity of sequences specified by RNA is a direct function of its length, composition, and nucleotide permutation. RNA sequence space exceeds that of the proteome, as there is virtually no limit as to how long a macroRNA can be. A single transcription unit can identify a unique position in the genome. In contrast, transcription factors and other DNA-binding proteins recognize DNA motifs of a limited number of basepairs and the number of possible binding sites is therefore generally $>>1$, enabling a transcription factor to operate within a large regulatory network. For instance, the transcription factor and chromatin insulator, Ctcf, binds a 20-bp motif that appears thousands of times in the genome, and the pluripotency factor, Oct4, likewise binds an 8-bp motif with many genomic repetitions (Kim et al. 2007; Chen et al. 2008). On the other hand, the Tsix and RepA ncRNAs occur only once, specifically at the Xic. Therefore, whereas transcription factors tend to function within a large gene network, long ncRNA can specify a unique address in the genome.

The concept of an "RNA guide" to target chromatin modifiers takes RNA away from its well-recognized role as intermediary between genotype (DNA) and phenotype ( protein) and shifts it toward a dynamic role in epigenome control. RNA-mediated targeting need not be restricted to the $\mathrm{X}$. PRC2 has also been associated, either directly or indirectly, with autosomal ncRNAs such as HOTAIR (Rinn et al. 2007; Khalil et al. 2009) and Kcnqtlot1 (Pandey et al. 2008). Other chromatin modifiers, such as the de novo DNA methyltransferase Dnmt3a (Sun et al. 2006) and the H3-K9 methylase G9a (Nagano et al. 2008), may also be regulated by long ncRNA, as suggested by RNAChIP. Further work is required to determine if there is direct RNA-protein interaction or if the proteins are recruited by the underlying chromatin, of which RNA may be one component. An RNAmediated mechanism may explain why many chromatin modifiers lack a sequence-specific DNA-binding activity but often harbor RNA-binding motifs (Denisenko et al. 1998; Bernstein and Allis 2005; Bernstein et al. 2006).

With an ever-growing number of long ncRNAs being discovered across the genome (Claverie 2005; Kapranov et al. 2007a; Kapranov et al. 2007b; Guttman et al. 2009; Mercer et al. 2009), it is easy to imagine that RNA guidance may become a recurrent strategy in epigenomic regulation. Interchromosomal associations have been similarly proposed to underlie allelic choice at autosomal loci (LaSalle and Lalande 1996; Spilianakis et al. 2005; Lomvardas et al. 2006), begging the question of whether transcription and RNA guide these trans-interactions. Furthermore, many genes harbor antisense RNA (Katayama et al. 2005; He et al. 2008), raising the possibility of RNA-mediated recruitment of chromatin modifiers at those loci as well. On the X-chromosome, ncRNA's full range of function has yet to be explored fully, given that many Xic-linked ncRNAs remain uncharacterized.

As we discover more examples of regulation by long ncRNA, one might predict that the large transcripts will eventually rival small RNAs and proteins in their versatility as epigenetic regulators. This article has argued that long ncRNAs are particularly well-suited to allelic regulation and to any action that requires locus-specific targeting and communication in cis. Thus, the vast intergenic sequence space that was once widely thought to harbor "junk" may actually be primary determinants of phenotypic variation within and among species. Closely related organisms (e.g., humans versus chimps, mice versus rats), and even individuals of a species, are virtually identical in their "ORF-omes" but can vary significantly in their transcriptomes. For example, differences in coat color and disease susceptibility have been attributed to a retrotransposon near the Agouti gene in mice (Waterland and Jirtle 2003; Blewitt et al. 2006). Human cancer and metastasis have been associated with loss of regulation by long ncRNAs, including MALAT1 for lung adenocarcinomas, 
GTL2 in neuronal tumors, and H19 for Wilms tumor (Lin et al. 2007; Edwards et al. 2008; Wan and Bartolomei 2008; Wilusz et al. 2008). Interestingly, many of these RNAs operate in cis. Before long, we may be looking into the ncRNA world, as a matter of routine, for answers to many questions relating to health and disease.

\section{ACKNOWLEDGMENTS}

I am greatly indebted to all members of my lab for their invaluable discussions, insights, and inspiration. Work described in this article has been sponsored by either the National Institutes of Health. (RO1-GM58839) or by the HHMI, where JTL is an investigator.

\section{REFERENCES}

Anguera MC, Sun BK, Xu N, Lee JT. 2006. X-chromosome kiss and tell: How the Xs go their separate ways. Cold Spring Harb Symp Quant Biol 71: 429-437.

Avner P, Heard E. 2001. X-chromosome inactivation: Counting, choice and initiation. Nat Rev Genet 2: 59-67.

Bacher CP, Guggiari M, Brors B, Augui S, Clerc P, Avner P, Eils R, Heard E. 2006. Transient colocalization of $X$-inactivation centres accompanies the initiation of X inactivation. Nat Cell Biol 8: 293-299.

Bartolomei MS, Zemel S, Tilghman SM. 1991. Parental imprinting of the mouse H19 gene. Nature 351: 153-155.

Bell AC, West AG, Felsenfeld G. 1999. The protein CTCF is required for the enhancer blocking activity of vertebrate insulators. Cell 98: 387-396.

Bernstein E, Allis CD. 2005. RNA meets chromatin. Genes Dev 19: $1635-1655$.

Bernstein E, Duncan EM, Masui O, Gil J, Heard E, Allis CD. 2006. Mouse polycomb proteins bind differentially to methylated histone $\mathrm{H} 3$ and RNA and are enriched in facultative heterochromatin. Mol Cell Biol 26: $2560-2569$.

Blewitt ME, Vickaryous NK, Paldi A, Koseki H, Whitelaw E. 2006. Dynamic reprogramming of DNA methylation at an epigenetically sensitive allele in mice. PLoS Genet 2: e49.

Borsani G, Tonlorenzi R, Simmler MC, Dandolo L, Arnaud D, Capra V, Grompe M, Pizzuti A, Muzny D, Lawrence C, et al. 1991. Characterization of a murine gene expressed from the inactive $\mathrm{X}$ chromosome. Nature 351: 325-329.

Boumil RM, Lee JT. 2001. Forty years of decoding the silence in X-chromosome inactivation. Hum Mol Genet 10: 2225-2232.

Brannan CI, Dees EC, Ingram RS, Tilghman SM. 1990. The product of the H19 gene may function as an RNA. Mol Cell Biol 10: 28-36.

Brockdorff N, Ashworth A, Kay GF, McCabe VM, Norris DP, Cooper PJ, Swift S, Rastan S. 1992. The product of the mouse Xist gene is a $15 \mathrm{~kb}$ inactive $\mathrm{X}$-specific transcript containing no conserved ORF and located in the nucleus. Cell 71: 515-526.

Brown CJ, Ballabio A, Rupert JL, Lafreniere RG, Grompe M, Tonlorenzi R, Willard HF. 1991a. A gene from the region of the human X inactivation centre is expressed exclusively from the inactive $\mathrm{X}$ chromosome. Nature 349: 38-44.

Brown CJ, Hendrich BD, Rupert JL, Lafreniere RG, Xing Y, Lawrence J, Willard HF. 1992. The human XIST gene: Analysis of a $17 \mathrm{~kb}$ inactive $\mathrm{X}$-specific RNA that contains conserved repeats and is highly localized within the nucleus. Cell 71: 527-542.

Brown CJ, Lafreniere RG, Powers VE, Sebastio G, Ballabio A, Pettigrew AL, Ledbetter DH, Levy E, Craig IW, Willard HF. 1991b. Localization of the X inactivation centre on the human X chromosome in Xq13. Nature 349: 82-84.

Cam HP, Chen ES, Grewal SI. 2009. Transcriptional scaffolds for heterochromatin assembly. Cell 136: 610-614.

Carninci P, Kasukawa T, Katayama S, Gough J, Frith MC, Maeda N, Oyama R, Ravasi T, Lenhard B, Wells C, et al. 2005. The transcriptional landscape of the mammalian genome. Science 309: 1559-1563.

Cattanach BM, Isaacson JH. 1967. Controlling elements in the mouse X chromosome. Genetics 57: 331-346.

Cech TR. 2009. Crawling out of the RNA world. Cell 136: 599-602.

Chao W, Huynh KD, Spencer RJ, Davidow LS, Lee JT. 2002. CTCF, a candidate trans-acting factor for X-inactivation choice. Science 295: $345-347$.

Chen X, Xu H, Yuan P, Fang F, Huss M, Vega VB, Wong E, Orlov YL, Zhang W, Jiang J, et al. 2008. Integration of external signaling pathways with the core transcriptional network in embryonic stem cells. Cell 133: $1106-1117$.

Chureau C, Prissette M, Bourdet A, Barbe V, Cattolico L, Jones L, Eggen A, Avner P, Duret L. 2002. Comparative sequence analysis of the $\mathrm{X}$-inactivation center region in mouse, human, and bovine. Genome Res 12: 894-908.

Claverie JM. 2005. Fewer genes, more noncoding RNA. Science 309: $1529-1530$.

Clemson CM, McNeil JA, Willard HF, Lawrence JB. 1996. XIST RNA paints the inactive $\mathrm{X}$ chromosome at interphase: Evidence for a novel RNA involved in nuclear/chromosome structure. J Cell Biol 132: 259-275.

Clerc P, Avner P. 1998. Role of the region 3' to Xist exon 6 in the counting process of X-chromosome inactivation. Nat Genet 19: 249-253.

Cohen DE, Davidow LS, Erwin JA, Xu N, Warshawsky D, Lee JT. 2007. The DXPas34 repeat regulates random and imprinted X inactivation. Dev Cell 12: 57-71.

Courtier B, Heard E, Avner P. 1995. Xce haplotypes show modified methylation in a region of the active $\mathrm{X}$ chromosome lying 3' to Xist. Proc Natl Acad Sci 92: 3531-3535.

Davidow LS, Breen M, Duke SE, Samollow PB, McCarrey JR, Lee JT. 2007. The search for a marsupial XIC reveals a break with vertebrate synteny. Chromosome Res 15: 137-146.

Debrand E, Chureau C, Arnaud D, Avner P, Heard E. 1999. Functional analysis of the DXPas34 locus, a 3' regulator of Xist expression. Mol Cell Biol 19: 8513-8525.

Denisenko O, Shnyreva M, Suzuki H, Bomsztyk K. 1998. Point mutations in the WD40 domain of Eed block its interaction with Ezh2. Mol Cell Biol 18: 5634-5642.

Donohoe ME, Silva SS, Pinter SF, Xu N, Lee JT. 2009. The pluripotency factor Oct4 interacts with Ctcf and also controls X-chromosome pairing and counting. Nature 460: 128-132.

Donohoe ME, Zhang LF, Xu N, Shi Y, Lee JT. 2007. Identification of a Ctcf cofactor, Yy1, for the X chromosome binary switch. Mol Cell 25: $43-56$.

Duret L, Chureau C, Samain S, Weissenbach J, Avner P. 2006. The Xist RNA gene evolved in eutherians by pseudogenization of a proteincoding gene. Science 312: 1653-1655.

Edwards CA, Ferguson-Smith AC. 2007. Mechanisms regulating imprinted genes in clusters. Curr Opin Cell Biol 19: 281-289.

Edwards CA, Mungall AJ, Matthews L, Ryder E, Gray DJ, Pask AJ, Shaw G, Graves JA, Rogers J, Dunham I, et al. 2008. The evolution of the DLK1-DIO3 imprinted domain in mammals. PLoS Biol 6: e135.

Ghildiyal M, Zamore PD. 2009. Small silencing RNAs: an expanding universe. Nat Rev Genet 10: 94-108.

Guttman M, Amit I, Garber M, French C, Lin MF, Feldser D, Huarte M, Zuk O, Carey BW, Cassady JP, et al. 2009. Chromatin signature reveals over a thousand highly conserved large non-coding RNAs in mammals. Nature 458: 223-227.

He Y, Vogelstein B, Velculescu VE, Papadopoulos N, Kinzler KW. 2008. The antisense transcriptomes of human cells. Science 322: 1855-1857. 
Hoki Y, Kimura N, Kanbayashi M, Amakawa Y, Ohhata T, Sasaki H, Sado T. 2009. A proximal conserved repeat in the Xist gene is essential as a genomic element for X-inactivation in mouse. Development 136: $139-146$.

Hore TA, Koina E, Wakefield MJ, Marshall Graves JA. 2007. The region homologous to the $\mathrm{X}$-chromosome inactivation centre has been disrupted in marsupial and monotreme mammals. Chromosome Res 15: $147-161$.

Johnston CM, Newall AE, Brockdorff N, Nesterova TB. 2002. Enox, a novel gene that maps $10 \mathrm{~kb}$ upstream of Xist and partially escapes $\mathrm{X}$ inactivation. Genomics 80: 236-244.

Kanellopoulou C, Muljo SA, Dimitrov SD, Chen X, Colin C, Plath K, Livingston DM. 2009. X chromosome inactivation in the absence of Dicer. Proc Natl Acad Sci 106: 1122-1127.

Kapranov P, Willingham AT, Gingeras TR. 2007b. Genome-wide transcription and the implications for genomic organization. Nat Rev Genet 8: 413-423.

Kapranov P, Cheng J, Dike S, Nix DA, Duttagupta R, Willingham AT, Stadler PF, Hertel J, Hackermuller J, Hofacker IL, et al. 2007a. RNA maps reveal new RNA classes and a possible function for pervasive transcription. Science 316: 1484-1488.

Katayama S, Tomaru Y, Kasukawa T, Waki K, Nakanishi M, Nakamura M, Nishida H, Yap CC, Suzuki M, Kawai J, et al. 2005. Antisense transcription in the mammalian transcriptome. Science 309: 1564-1566.

Kay GF, Barton SC, Surani MA, Rastan S. 1994. Imprinting and X chromosome counting mechanisms determine Xist expression in early mouse development. Cell 77: 639-650.

Khalil AM, Guttman M, Huarte M, Garber M, Raj A, Rivea Morales D, Thomas K, Presser A, Bernstein BE, van Oudenaarden A, et al. 2009. Many human large intergenic noncoding RNAs associate with chromatin-modifying complexes and affect gene expression. Proc Natl Acad Sci 106: 11667-11672.

Kim TH, Abdullaev ZK, Smith AD, Ching KA, Loukinov DI, Green RD, Zhang MQ, Lobanenkov VV, Ren B. 2007. Analysis of the vertebrate insulator protein CTCF-binding sites in the human genome. Cell 128: $1231-1245$

Kohlmaier A, Savarese F, Lachner M, Martens J, Jenuwein T, Wutz A. 2004. A chromosomal memory triggered by Xist regulates histone methylation in X inactivation. PLoS Biol 2: E171.

LaSalle JM, Lalande M. 1996. Homologous association of oppositely imprinted chromosomal domains. Science 272: 725-728.

Lee JT. 2000. Disruption of imprinted X inactivation by parent-of-origin effects at Tsix. Cell 103: 17-27.

Lee JT. 2002. Homozygous Tsix mutant mice reveal a sex-ratio distortion and revert to random X-inactivation. Nat Genet 32: 195-200.

Lee JT. 2005. Regulation of X-chromosome counting by Tsix and Xite sequences. Science 309: 768-771.

Lee JT. 2009. Lessons from X-chromosome inactivation: Long ncRNA as guides and tethers to the epigenome. Genes Dev 23: 1831-1842.

Lee JT, Lu N. 1999. Targeted mutagenesis of Tsix leads to nonrandom X inactivation. Cell 99: 47-57.

Lee JT, Davidow LS, Warshawsky D. 1999a. Tsix, a gene antisense to Xist at the X-inactivation centre. Nat Genet 21: 400-404.

Lee JT, Lu N, Han Y. 1999b. Genetic analysis of the mouse X inactivation center defines an 80-kb multifunction domain. Proc Natl Acad Sci 96: $3836-3841$.

Lee JT, Strauss WM, Dausman JA, Jaenisch R. 1996. A $450 \mathrm{~kb}$ transgene displays properties of the mammalian X-inactivation center. Cell 86: $83-94$.

Lin R, Maeda S, Liu C, Karin M, Edgington TS. 2007. A large noncoding RNA is a marker for murine hepatocellular carcinomas and a spectrum of human carcinomas. Oncogene 26: 851-858.

Lobanenkov VV, Nicolas RH, Adler VV, Paterson H, Klenova EM, Polotskaja AV, Goodwin GH. 1990. A novel sequence-specific DNA binding protein which interacts with three regularly spaced direct repeats of the CCCTC-motif in the 5' flaking sequence of the chicken c-myc gene. Oncogene 5: 1743-1753.
Lomvardas S, Barnea G, Pisapia DJ, Mendelsohn M, Kirkland J, Axel R. 2006. Interchromosomal interactions and olfactory receptor choice. Cell 126: 403-413.

Lucchesi JC, Kelly WG, Panning B. 2005. Chromatin remodeling in dosage compensation. Annu Rev Genet 39: 615-651.

Luikenhuis S, Wutz A, Jaenisch R. 2001. Antisense transcription through the Xist locus mediates Tsix function in embryonic stem cells. Mol Cell Biol 21: 8512-8520.

Lyon MF. 1961. Gene action in the X-chromosome of the mouse (Mus musculus L.). Nature 190: 372-373.

Lyon MF. 1999. Imprinting and X chromosome inactivation. In Results and problems in cell differentiation (ed. R Ohlsson), pp. 73-90. Springer-Verlag, Heidelberg.

Marahrens Y. 1999. X-inactivation by chromosomal pairing events. Genes Dev 13: 2624-2632.

Marahrens Y, Panning B, Dausman J, Strauss W, Jaenisch R. 1997. Xistdeficient mice are defective in dosage compensation but not spermatogenesis. Genes Dev 11: 156-166.

Masui O, Heard E. 2006. RNA and protein actors in X-chromosome inactivation. Cold Spring Harb Symp Quant Biol 71: 419-428.

Mercer TR, Dinger ME, Mattick JS. 2009. Long non-coding RNAs: Insights into functions. Nat Rev Genet 10: 155-159.

Moazed D. 2009. Small RNAs in transcriptional gene silencing and genome defense. Nature 457: 413-420.

Monk M, Harper MI. 1979. Sequential X chromosome inactivation coupled with cellular differentiation in early mouse embryos. Nature 281: $311-313$.

Monkhorst K, de Hoon B, Jonkers I, Mulugeta Achame E, Monkhorst W, Hoogerbrugge J, Rentmeester E, Westerhoff HV, Grosveld F, Grootegoed JA, et al. 2009. The probability to initiate X chromosome inactivation is determined by the $\mathrm{X}$ to autosomal ratio and $\mathrm{X}$ chromosome specific allelic properties. PLoS ONE 4: e5616.

Morey C, Navarro P, Debrand E, Avner P, Rougeulle C, Clerc P. 2004. The region 3' to Xist mediates X chromosome counting and H3 Lys-4 dimethylation within the Xist gene. Embo J 23: 594-604.

Nagano T, Mitchell JA, Sanz LA, Pauler FM, Ferguson-Smith AC, Feil R, Fraser P. 2008. The Air noncoding RNA epigenetically silences transcription by targeting G9a to chromatin. Science 322: 1717-1720.

Navarro P, Chambers I, Karwacki-Neisius V, Chureau C, Morey C, Rougeulle C, Avner P. 2008. Molecular coupling of Xist regulation and pluripotency. Science 321: 1693-1695.

Navarro P, Page DR, Avner P, Rougeulle C. 2006. Tsix-mediated epigenetic switch of a CTCF-flanked region of the Xist promoter determines the Xist transcription program. Genes Dev 20: 2787-2792.

Navarro P, Pichard S, Ciaudo C, Avner P, Rougeulle C. 2005. Tsix transcription across the Xist gene alters chromatin conformation without affecting Xist transcription: Implications for X-chromosome inactivation. Genes Dev 19: 1474-1484.

Nesterova TB, Popova BC, Cobb BS, Norton S, Senner CE, Tang YA, Spruce T, Rodriguez TA, Sado T, Merkenschlager M, et al. 2008. Dicer regulates Xist promoter methylation in ES cells indirectly through transcriptional control of Dnmt3a. Epigenetics Chromatin 1: 2.

Nicodemi M, Prisco A. 2007a. Self-assembly and DNA binding of the blocking factor in $\mathrm{x}$ chromosome inactivation. PLoS Comput Biol 3: e210.

Nicodemi M, Prisco A. 2007b. Symmetry-breaking model for X-chromosome inactivation. Phys Rev Lett 98: 108104.

Nicodemi M, Panning B, Prisco A. 2008. A thermodynamic switch for chromosome colocalization. Genetics 179: 717-721.

Ogawa Y, Lee JT. 2003. Xite, X-inactivation intergenic transcription elements that regulate the probability of choice. Mol Cell 11: 731-743.

Ogawa Y, Sun BK, Lee JT. 2008. Intersection of the RNA interference and $\mathrm{X}$-inactivation pathways. Science 320: 1336-1341.

Ohhata T, Hoki Y, Sasaki H, Sado T. 2006. Tsix-deficient X chromosome does not undergo inactivation in the embryonic lineage in males: Implications for Tsix-independent silencing of Xist. Cytogenet Genome Res 113: 345-349. 
Ohhata T, Hoki Y, Sasaki H, Sado T. 2008. Crucial role of antisense transcription across the Xist promoter in Tsix-mediated Xist chromatin modification. Development 135: 227-235.

Ohlsson R, Renkawitz R, Lobanenkov VV. 2001. CTCF is a uniquely versatile transcription regulator linked to epigenetics and disease. Trends Genet 7: 520-527.

Pandey RR, Mondal T, Mohammad F, Enroth S, Redrup L, Komorowski J, Nagano T, Mancini-Dinardo D, Kanduri C. 2008. Kcnqlot1 antisense noncoding RNA mediates lineage-specific transcriptional silencing through chromatin-level regulation. Mol Cell 32: 232-246.

Payer B, Lee JT. 2008. X Chromosome dosage compensation: How mammals keep the balance. Annu Rev Genet 42: 733-772.

Penny GD, Kay GF, Sheardown SA, Rastan S, Brockdorff N. 1996. Requirement for Xist in X chromosome inactivation. Nature 379: $131-137$

Plath K, Fang J, Mlynarczyk-Evans SK, Cao R, Worringer KA, Wang H, de la Cruz CC, Otte AP, Panning B, Zhang Y. 2003. Role of histone $\mathrm{H} 3$ lysine 27 methylation in X inactivation. Science 300: 131-135.

Plath K, Mlynarczyk-Evans S, Nusinow DA, Panning B. 2002. Xist RNA and the mechanism of X chromosome inactivation. Annu Rev Genet 36: $233-278$.

Rastan S, Robertson EJ. 1985. X-chromosome deletions in embryoderived (EK) cell lines associated with lack of X-chromosome inactivation. J Embryol Exp Morphol 90: 379-388.

Ringrose L, Paro R. 2004. Epigenetic regulation of cellular memory by the Polycomb and Trithorax group proteins. Annu Rev Genet 38: 413-443.

Rinn JL, Kertesz M, Wang JK, Squazzo SL, Xu X, Brugmann SA, Goodnough LH, Helms JA, Farnham PJ, Segal E, et al. 2007. Functional demarcation of active and silent chromatin domains in human HOX loci by noncoding RNAs. Cell 129: 1311-1323.

Sado T, Hoki Y, Sasaki H. 2005. Tsix silences Xist through modification of chromatin structure. Dev Cell 9: 159-165.

Sado T, Hoki Y, Sasaki H. 2006. Tsix defective in splicing is competent to establish Xist silencing. Development 133: 4925-4931.

Sado T, Li E, Sasaki H. 2002. Effect of TSIX disruption on XISTexpression in male ES cells. Cytogenet Genome Res 99: 115-118.

Sado T, Okano M, Li E, Sasaki H. 2004. De novo DNA methylation is dispensable for the initiation and propagation of $\mathrm{X}$ chromosome inactivation. Development 131: 975-982.

Sado T, Wang Z, Sasaki H, Li E. 2001. Regulation of imprinted $\mathrm{X}$-chromosome inactivation in mice by Tsix. Development 128: 1275-1286.

Schwartz YB, Pirrotta V. 2008. Polycomb complexes and epigenetic states. Curr Opin Cell Biol 20: 266-273.

Sharman GB. 1971. Late DNA replication in the paternally derived X chromosome of female kangaroos. Nature 230: 231-232.

Sharp PA. 2009. The centrality of RNA. Cell 136: 577-580.

Shevchenko AI, Zakharova IS, Elisaphenko EA, Kolesnikov NN, Whitehead S, Bird C, Ross M, Weidman JR, Jirtle RL, Karamysheva TV, et al. 2007. Genes flanking Xist in mouse and human are separated on the X chromosome in American marsupials. Chromosome Res 15: 127-136.

Shibata S, Lee JT. 2003. Characterization and quantitation of differential Tsix transcripts: implications for Tsix function. Hum Mol Genet 12: $125-136$

Shibata S, Lee JT. 2004. Tsix transcription- versus RNA-based mechanisms in Xist repression and epigenetic choice. Curr Biol 14: $1747-1754$.
Shibata S, Yokota T, Wutz A. 2008. Synergy of Eed and Tsix in the repression of Xist gene and X-chromosome inactivation. Embo J 27: 18161826.

Silva J, Mak W, Zvetkova I, Appanah R, Nesterova TB, Webster Z, Peters AH, Jenuwein T, Otte AP, Brockdorff N. 2003. Establishment of histone h3 methylation on the inactive $\mathrm{X}$ chromosome requires transient recruitment of Eed-Enx1 polycomb group complexes. Dev Cell 4: 481-495.

Simmler MC, Cunningham DB, Clerc P, Vermat T, Caudron B, Cruaud C, Pawlak A, Szpirer C, Weissenbach J, Claverie JM, et al. 1996. A $94 \mathrm{~kb}$ genomic sequence 3' to the murine Xist gene reveals an AT rich region containing a new testis specific gene Tsx. Hum Mol Genet 5: $1713-1726$.

Spilianakis CG, Lalioti MD, Town T, Lee GR, Flavell RA. 2005. Interchromosomal associations between alternatively expressed loci. Nature 435: 637-645.

Stavropoulos N, Lu N, Lee JT. 2001. A functional role for Tsix transcription in blocking Xist RNA accumulation but not in X-chromosome choice. Proc Natl Acad Sci 98: 10232-10237.

Stavropoulos N, Rowntree RK, Lee JT. 2005. Identification of developmentally specific enhancers for Tsix in the regulation of X chromosome inactivation. Mol Cell Biol 25: 2757-2769.

Sun BK, Deaton AM, Lee JT. 2006. A transient heterochromatic state in Xist preempts X inactivation choice without RNA stabilization. Mol Cell 21: 617-628.

Wan LB, Bartolomei MS. 2008. Regulation of imprinting in clusters: Noncoding RNAs versus insulators. Adv Genet 61: 207-223.

Waterland RA, Jirtle RL. 2003. Transposable elements: Targets for early nutritional effects on epigenetic gene regulation. Mol Cell Biol 23: 5293-5300.

Wheeler DL, Barrett T, Benson DA, Bryant SH, Canese K, Chetvernin V, Church DM, Dicuccio M, Edgar R, Federhen S, et al. 2008. Database resources of the National Center for Biotechnology Information. Nucleic Acids Res 36: D13-21.

Willard HF. 1996. X chromosome inactivation, XIST, and pursuit of the X-inactivation center. Cell 86: 5-7.

Wilusz JE, Freier SM, Spector DL. 2008. 3' end processing of a long nuclear-retained noncoding RNA yields a tRNA-like cytoplasmic RNA. Cell 135: 919-932.

Wutz A. 2003. RNAs templating chromatin structure for dosage compensation in animals. Bioessays 25: 434-442.

Wutz A, Gribnau J. 2007. X inactivation Xplained. Curr Opin Genet Dev 17: 387-393.

Wutz A, Rasmussen TP, Jaenisch R. 2002. Chromosomal silencing and localization are mediated by different domains of Xist RNA. Nat Genet 30: $167-174$.

Wutz A, Smrzka OW, Schweifer N, Schellander K, Wagner EF, Barlow DP. 1997. Imprinted expression of the Igf2r gene depends on an intronic CpG island. Nature 389: 745-749.

Xu N, Tsai CL, Lee JT. 2006. Transient homologous chromosome pairing marks the onset of X inactivation. Science 311: 1149-1152.

Xu N, Donohoe ME, Silva SS, Lee JT. 2007. Evidence that homologous $\mathrm{X}$-chromosome pairing requires transcription and Ctcf protein. Nat Genet 39: 1390-1396.

Zhao J, Sun BK, Erwin JA, Song JJ, Lee JT. 2008. Polycomb proteins targeted by a short repeat RNA to the mouse X chromosome. Science 322: $750-756$. 


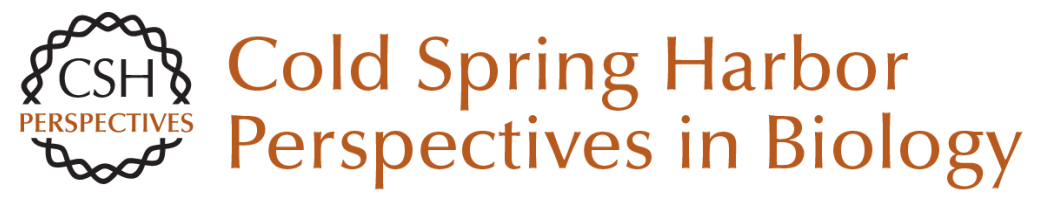

\section{The $\mathrm{X}$ as Model for RNA's Niche in Epigenomic Regulation}

Jeannie T. Lee

Cold Spring Harb Perspect Biol 2010; doi: 10.1101/cshperspect.a003749 originally published online March 31, 2010

\section{Subject Collection RNA Worlds}

Alternate RNA Structures

Marie Teng-Pei Wu and Victoria D'Souza

Approaches for Understanding the Mechanisms

of Long Noncoding RNA Regulation of Gene

Expression

Patrick McDonel and Mitchell Guttman

Principles and Practices of Hybridization Capture

Experiments to Study Long Noncoding RNAs That

Act on Chromatin

Matthew D. Simon and Martin Machyna

Linking RNA Sequence, Structure, and Function

on Massively Parallel High-Throughput

Sequencers

Sarah K. Denny and William J. Greenleaf

Extensions, Extra Factors, and Extreme

Complexity: Ribosomal Structures Provide

Insights into Eukaryotic Translation

Melanie Weisser and Nenad Ban

Nascent RNA and the Coordination of Splicing with Transcription

Karla M. Neugebauer

Combining Mass Spectrometry (MS) and Nuclear Magnetic Resonance (NMR) Spectroscopy for Integrative Structural Biology of Protein-RNA Complexes

Alexander Leitner, Georg Dorn and Frédéric H.-T. Allain
Structural Biology of Telomerase

Yaqiang Wang, Lukas Susac and Juli Feigon

Structural Insights into Nuclear pre-mRNA

Splicing in Higher Eukaryotes

Berthold Kastner, Cindy L. Will, Holger Stark, et al.

What Are 3' UTRs Doing?

Christine Mayr

\section{Single-Molecule Analysis of Reverse}

Transcriptase Enzymes

Linnea I. Jansson and Michael D. Stone

\section{CRISPR Tools for Systematic Studies of RNA}

Regulation

Jesse Engreitz, Omar Abudayyeh, Jonathan Gootenberg, et al.

Relating Structure and Dynamics in RNA Biology Kevin P. Larsen, Junhong Choi, Arjun Prabhakar, et al.

Beyond DNA and RNA: The Expanding Toolbox of

Synthetic Genetics Alexander I. Taylor, Gillian Houlihan and Philipp Holliger

For additional articles in this collection, see http://cshperspectives.cshlp.org/cgi/collection/

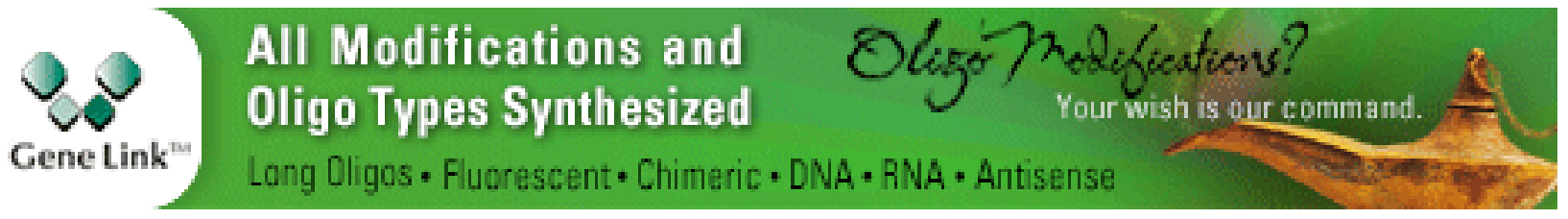


Discovering and Mapping the Modified Nucleotides That Comprise the Epitranscriptome of mRNA

Bastian Linder and Samie R. Jaffrey
Structural Basis of Nuclear pre-mRNA Splicing:

\section{Lessons from Yeast}

Clemens Plaschka, Andrew J. Newman and Kiyoshi Nagai

For additional articles in this collection, see http://cshperspectives.cshlp.org/cgi/collection/

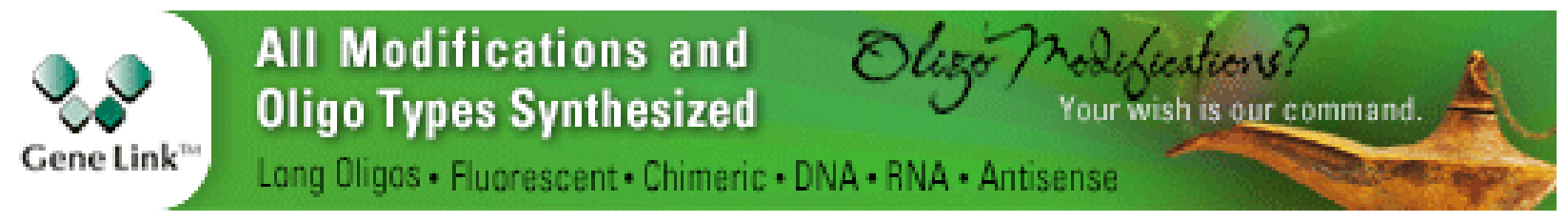

Copyright (C) 2010 Cold Spring Harbor Laboratory Press; all rights reserved 